\title{
Ensuring economic safety: regional aspects
}

\author{
Anastasia Gontar \\ Volgograd State Technical University \\ Chair of Applied Mathematics \\ Volgograd, Russia \\ 261984@mail.ru
}

\begin{abstract}
At present the process of economic upgrade is most actively expressed on the regional level. The current unfavorable foreign economic situation, sanctioned barriers, lost access to foreign markets of capital and technologies, mistrust call for revision of methodological approaches, used both to insure national economic safety and to realize mechanisms, which guarantee economic safety of regional economic entities. This emphasizes the importance of optimizing the existing approaches to insuring economic safety of the regional banking system, as it is exactly the credit organizations, which act as mediators between the state and economic entities. During the research we specified the notion "regional banking system", identified key factors, affecting the functional stability of territorial entities, proposed methods to assess the economic safety level of regional credit organizations. We evaluated the economic safety level of Federal districts in the Russian Federation, as well as made comparative analysis of the results achieved. The scientific paper materials demonstrate the possibility to use efficiently the proposed methods to evaluate the economic safety level of the regional banking system.
\end{abstract}

Keywords - regional banking system, economic safety, credit organization, modelling

\section{INTRODUCTION}

The current unfavorable foreign economic situation, sanctioned barriers, lost access to foreign markets of capital and technologies, consistently low prices of hydrocarbons, call for revision of methodological approaches, used both to insure national economic safety and to realize mechanisms, which guarantee economic safety of regional economic entities [1, 2].

Multiple social \& economic problems in a number of Russian Federation regions necessitate a search for new ways to insure stable economic development with due account for regional specific features. Since the credit \& monetary relations between the state and economic entities are realized through a financial sector, the scope of investment to the regional economy depends exactly upon the activeness of credit organizations. This situation emphasizes the importance of examining the activities of regional banks from the point of their influence on the economic safety level in the Russian Federation regions. This necessitates solution of the following tasks:

- Determinig the role and place of credit organizations in the system of insuring regional economic safety.
- Identifying indices of regional banking system status, affecting the economic safety level [3].

Most important from the point of mastering the specific features of regional economic development, various theoretical and practical aspects in providing economic safety of credit organization, are in our view, works by I. Yu. Variash, M.P. Matovnikov, L.I. Abalkin, A.I. Arkhipov, V.V. Ivanov, N.S. Pavlov, A.I. Galushkin and others [4, 5, 6].

But analyzed in the economic literature are only separate aspects of the phenomenon, ignoring mutual influence of the banking system components and their impact on the regional economic safety. This fact weakens considerably the practical feasibility of the research under way. What we need is comprehensive research of regional aspects in providing economic safety $[7,8,9]$.

The purpose of the research is to offer, based on theoretical $\&$ methodological provisions and notions, methods to assess the economic safety level of the regional banking system, as well as come up with practical recommendations on their application.

\section{MATERIALS AND METHODS (MODEL)}

Theoretical basis for the research was: general theory of national safety; materials of international economic research; Federal \& regional statistic agencies; development strategy \& programs; theoretical works of Russian and foreign scientists on the role of banking \& credit system in development of regional economy .

Study of specific features for insuring economic safety of regional credit organizations should commence with core terminological notions. Analysis of economic literature gives an idea about the status of issue under research, summarize available approaches and define the regional banking system as a key link of the regional financial sector, accumulating all cash flows in the sphere of economic activity of a territorial subject.

A major advantage of territorial banks is their ability to adapt within short time to turbulent macro and micro conditions. Such mobility of regional credit organizations, contributes, first of all, to better investment appeal, as the funds are not taken out of the territory, which boosts the resource basis of a territorial subject. But leading economists have different opinions as to the prospects of regional banks. Some think that such banks are more sensitive to interests and 
needs of local population, business and authorities. Others advocate enlargement of the banking system, as big banks are more diverse $[9,10,11]$.

According to the author, regional banks have more efficient risk management, as due to objective reasons they need shorter time to attend to clients' responses and requests and to take a decision than big Federal banks. For example, even in the USA, possessing the largest in the world financial sector, on October 1, 2017 more than $78 \%$ of credit organizations (3852 out of 4938) were regional.

Formation of regional banking systems is not a uniform process, most assets are in the central part of the country $(57 \%)$. Vast areas of Ural, Northern and Far Eastern districts account for less than $14 \%$ of credit organizations. These results reflect the economic development trends of the Russian Federation territories. The structure of Russian Federation regional banking system for the last eleven years is shown in Table 1.

TABLE I. NUMBER OF WORKING BANKS IN THE RUSSIAN FEDERATION, 2008-2018

\begin{tabular}{|c|c|c|c|c|c|c|c|c|}
\hline & $\boldsymbol{1}$ & $\mathbf{2}$ & $\mathbf{3}$ & $\mathbf{4}$ & $\mathbf{5}$ & $\mathbf{6}$ & $\mathbf{7}$ & $\boldsymbol{8}$ \\
\hline & $\boldsymbol{C F D}$ & $\boldsymbol{N W F D}$ & $\boldsymbol{S F D}$ & $\boldsymbol{N C F D}$ & $\boldsymbol{V F D}$ & $\boldsymbol{U F D}$ & $\boldsymbol{S F D}$ & $\boldsymbol{F E F D}$ \\
\hline $\mathbf{2 0 0 8}$ & 632 & 81 & 118 & - & 134 & 63 & 68 & 40 \\
\hline $\mathbf{2 0 0 9}$ & 621 & 79 & 75 & - & 131 & 58 & 68 & 36 \\
\hline $\mathbf{2 0 1 0}$ & 598 & 75 & 113 & - & 125 & 54 & 62 & 31 \\
\hline $\mathbf{2 0 1 1}$ & 585 & 71 & 47 & 57 & 118 & 51 & 56 & 27 \\
\hline $\mathbf{2 0 1 2}$ & 572 & 69 & 45 & 56 & 111 & 45 & 54 & 26 \\
\hline $\mathbf{2 0 1 3}$ & 564 & 70 & 46 & 43 & 102 & 42 & 51 & 22 \\
\hline $\mathbf{2 0 1 4}$ & 547 & 70 & 46 & 43 & 102 & 42 & 51 & 22 \\
\hline $\mathbf{2 0 1 5}$ & 504 & 64 & 43 & 28 & 92 & 35 & 44 & 22 \\
\hline $\mathbf{2 0 1 6}$ & 434 & 60 & 37 & 22 & 85 & 32 & 41 & 17 \\
\hline $\mathbf{2 0 1 7}$ & 358 & 49 & 38 & 17 & 77 & 29 & 37 & 18 \\
\hline $\mathbf{2 0 1 8}$ & 319 & 43 & 35 & 17 & 71 & 26 & 32 & 18 \\
\hline
\end{tabular}

${ }^{\text {a. }}$ Based on materials of Statistical bullet of the Bank of Russia, 2008-2018

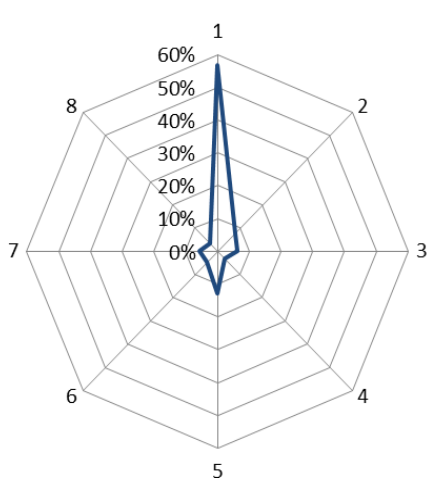

Fig. 1. Distribution of credit organizations in the Russian Federation by regions.
Used as a methodological basis of research was a neural network approach to analyze indices of regional credit organizations as a tool to form favourable conditions for development of territorial subjects.

For quantitative assessment of regional banking system economic safety level, identified during the research were the following key factors, affecting the functional stability of territorial subjects:

- Rating of investment activity.

- Level of innovative activity.

- Scope of investment in main assets.

- Scope of financial investment.

The selection of these macroeconomic indices is due to the fact that when we want to insure regional economic safety we ought to consider criteria, related to the state as a whole, as well as specific features of economic safety of credit organizations, operating in the region.

\section{RESULTS AND DISCUSSION}

Let us review the task of assessing economic safety level of regional banking system in the Russian Federation Federal districts.

To illustrate the methods we used macroeconomic indices of the regional banking system of Russia in 2017.

Survey data are shown by combinations of the following values:

- Rating of investment activity $\left(\mathrm{x}_{1}\right)$.

- Level of innovative activity $\left(\mathrm{x}_{2}\right)$.

- Scope of investment in main assets, \% per annum $\left(\mathrm{x}_{3}\right)$.

- Scope of financial investment, \% per annum $\left(\mathrm{x}_{4}\right)$.

Having identified the calculation data, we can proceed to calculation of safety function values $\left(\mathrm{F}_{\mathrm{ES}}\right)$.

It is worth noting that the process of making the comprehensive table is quite tiresome, as survey data are given in the Statistical bulletin only by the Russian Federation subjects. For example, to calculate the rating of investment attractiveness in the Central Federal district in 2017, you have to assess the rating of every subject in this district: Belgorod region, Bryansk region etc. (Table II).

Economic safety function $\mathrm{F}_{\mathrm{ES}}$ can be presented in the following way, see (1) $[12,13]$ :

$$
F_{E S}=\frac{A e^{2 B \frac{x_{1} \cdot x_{2} \cdot x_{3} \cdot x_{4}}{x_{1}+x_{2}+x_{3}+x_{4}}}-1}{A e^{2 B \cdot \frac{x_{1} \cdot x_{2} \cdot x_{3} \cdot x_{4}}{x_{1}+x_{2}+x_{3}+x_{4}}}+1} \text {, ade } A, B=\text { const. }
$$


TABLE II. RATING OF INVESTMENT ATTRACTIVENESS OF SUBJECTS IN THE CENTRAL FEDERAL DISTRICT IN 2017

\begin{tabular}{|c|c|}
\hline Subject & $\begin{array}{c}\text { Rating of investment } \\
\text { attractiveness }\end{array}$ \\
\hline Belgorod Region & 2 \\
\hline Bryansk Region & 6 \\
\hline Vladimir Region & 5 \\
\hline Voronezh Region & 3 \\
\hline Ivanovo Region & 9 \\
\hline Kaluga Region & 3 \\
\hline Kostroma Region & 6 \\
\hline Kursk Region & 4 \\
\hline Lipetsk Region & 3 \\
\hline Moscow Region & 2 \\
\hline Orel Region & 7 \\
\hline Ryazan Region & 6 \\
\hline Smolensk Region & 6 \\
\hline Tambov Region & 5 \\
\hline Tver Region & 7 \\
\hline Tula Region & 3 \\
\hline Yaroslavl Region & 5 \\
\hline Moscow & 1 \\
\hline
\end{tabular}

TABLE III. MAKROECONOMIC INDICES OF THE RUSSIAN REGIONAL BANKING SYSTEM, VALUES $F_{E S}$

\begin{tabular}{|c|c|c|c|c|c|}
\hline FD & $\boldsymbol{x}_{\boldsymbol{1}}$ & $\boldsymbol{x}_{\boldsymbol{2}}$ & $\boldsymbol{x}_{\boldsymbol{3}}$ & $\boldsymbol{x}_{\boldsymbol{4}}$ & $\boldsymbol{F}_{\boldsymbol{E}}$ \\
\hline CFD & 5 & 0.83 & 24 & 75 & 5490 \\
\hline NWFD & 4 & 0.45 & 12 & 8 & 188 \\
\hline SFD & 7 & 0.5 & 8 & 1 & 18 \\
\hline NCFD & 8 & 0.14 & 2 & 0.2 & 0.28 \\
\hline VFD & 5 & 1 & 14 & 5 & 283 \\
\hline UFD & 4 & 0.5 & 20 & 7 & 294 \\
\hline SFD & 7 & 0.58 & 9 & 3 & 72 \\
\hline FEFD & 4 & 0.56 & 8 & 1 & 19 \\
\hline
\end{tabular}

c. Based on materials of Statistical bullet of the Bank of Russia 2017

As suggested by the research, regional banks, located far away from Central Russia, are more vulnerable in current conditions. They still face difficulties in attracting deposits and investments. In our view, this is due to limited opportunities of the regional business (main clients of credit organizations), low level of qualified specialists and management, competition from branches of large Federal banks. At the same time, we should not underestimate the potential of territorial economic subjects. Proximity to markets, ability to adapt fast to turbulent economic conditions, mobility, high speed of taking decisions and signing deals are indisputable advantages of the regional banking system [14, 15].

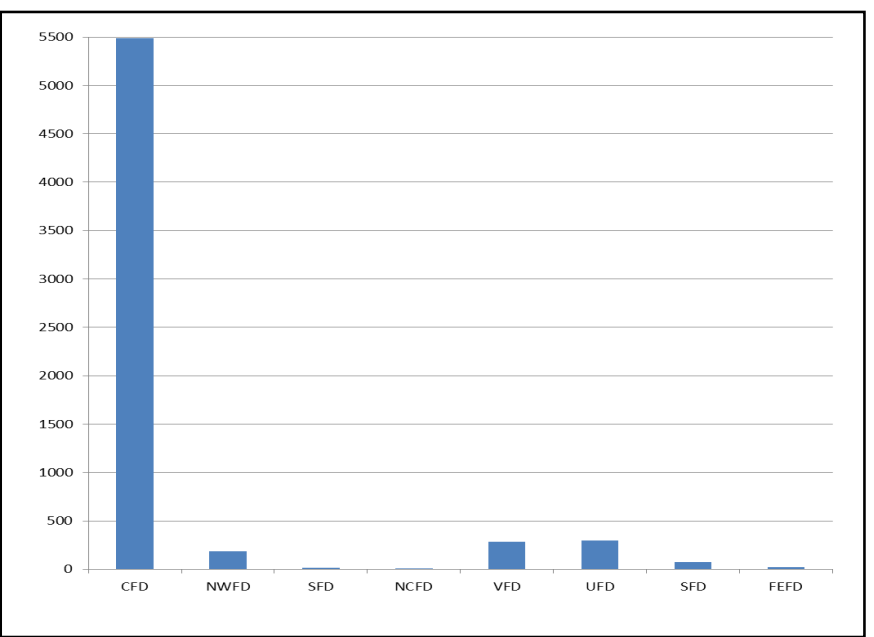

Fig. 2. Economic safety level of Russian Federation Federal districts

\section{CONCLUSION}

The practical importance of the offered methods to assess the economic safety level is that its application can create models with high degree of approximation, which guarantees objective analysis of experimental data.

Using in the capacity of survey data different indices, we can make a quantitative assessment of their impact on the economic safety level. More factors, used for making a summary table will naturally improve the practical importance of the results received.

It is obvious that the research and identification of factors, supporting stable development of territorial economic systems requires a more detailed analysis.

Studying the interaction and mutual relation of indices of financial sphere operation, as well as comprehensive approach to functioning of the regional banking system will make it possible to improve the Russian Federation investment attractiveness, which may lay basis for positive revisions in the social \& economic life of regions and the state as a whole.

A perspective direction of this research is building a selfteaching expert system, capable of modeling decision-making situations.

\section{References}

[1] Hull, J.C. Risk management and financial institutions / John C. Hull. 3rd ed. New-Jersey: Pearson education, 2012. 672 p.

[2] Ermakova, A.A. The indicators to measure the level of information security socio-economic systems [Pokazateli ocenki urovnya informacionnoj bezopasnosti social'no- ehkonomicheskih sistem]. New science: strategy and development vectors [Novaya nauka: strategii i vektory razvitiya],2016, vol. 8, pp. 183-185.

[3] Ermakova, A.A. Economic and Mathematical Modeling During Organization and Conduct of Business Games. Integration and Clustering for Sustainable Economic Growth. Editors: E.G. Popkova [et al.]. [Springer International Publishing AG], 2017, pp. 399-411. Available at: http://iupr.ru/domains_data/ files/zurnal_27/Gontar\%20A.A._Sovremennye\%20 tehnologii\%20upravleniya\%20organizaciyay.pdf. (Accessed 
December 2017) (Ser. Contributions to Economics). Available at: http://link.springer.com/book/10.1007\%2F978-3-319-45462-7\#page-1. (Accessed 14 January 2017)

[4] Litvinenko A.N., 2013. Economic and national security: the problem of concepts correlating // Scientific and technical statements, S.-Petersburg State Polytechnic University, Economic sciences, № 3 (173), pp. 9-15.

[5] Filatova, A.S. Investment security of the Russian Federation in modern conditions [Investicionnaya bezopasnost' Rossijskoj Federacii v sovremennyh usloviyah]. Young scientist [Molodoj uchenyj], 2015, vol. 1, pp. 304-307. (in Russian)

[6] Williamson O. The New Institutional Economics: Taking Stocks, Looking Ahead // Journal of Economic Literature. 2000. No. 3. P. 595613.

[7] Vodyanova, V.V. Institutional arrangements of economic security based on dynamic modeling of complex socio-economic systems. Dokt, Diss. [Razrabotka institucional'nyh mekhanizmov obespecheniya ehkonomicheskoj bezopasnosti na osnove dinamicheskogo modelirovaniya slozhnyh social'no-ehkonomicheskih sistem. Dokt, Diss.]. Moscow, 2010. 383 p.

[8] Latuta, O.V. Mathematical models and methods of economic security of Russian regions. Cand, Diss. [Matematicheskie modeli i metody obespecheniya ehkonomicheskoj bezopasnosti regionov Rossijskoj Federacii. Cand. Diss.] Saint Petersburg, 2006. 239 p.

[9] Gontar, A.A., Sazonov S.P. The economic methods for ensuring the information security of a credit institution [Ekonomicheskie metody obespecheniya informatsionnoi bezopasnosti kreditnoi organizatsii]. Management of economic systems: scientific electronic journal [Upravlenie ekonomicheskimi sistemami : elektron. nauch. zhurnal],
2016, vol.9, 7p. Available at: http://www.uecs.ru/teoriyaupravleniya/item/4064-2016-09-03-08-02-57 (Accessed 28 December 2017).

[10] Qinkun Xiao «Time series prediction using bayesian filtering model and fuzzy neural networks», Neural Networks, July 2017.

[11] Jie Wang, Jun Wang «Forecasting stochastic neural network based on financial empirical mode decomposition», Neural Networks, 2017.

[12] Gontar, A.A. Modern mathematical models of economic security of socio-economic systems [Sovremennye matematicheskie modeli obespecheniya ehkonomicheskoj bezopasnosti social'noehkonomicheskih sistem]. Economics and society [Ehkonomika i socium : ehlektron. Zhurnal], 2016, vol. 8, 5 p. Available at: http://iupr.ru/domains_data/ files/zurnal_27/Gontar\%20A.A._Sovremennye $\% 20$ tehnologii\%20upravleniya\%20organizaciyay.pdf. (Accessed 14 December 2017)

[13] Gontar, A.A., Isaev, A.V., Isaeva, L.A. Neural network modeling methodology of economic security [Metodologiya neirosetevogo modelirovaniya ekonomicheskoi bezopasnosti]. Discussion [diskussiya], 2017, no.8, pp. 16-20. (in Russian)

[14] Burkaltseva D.D., Tsohla S.Yu., Guk O.A., Borovskaia L.V., Bondar A.P. Basic forms of institutional changes of economy in Russia // International Journal of Applied Business and Economic Research. 2016. Vol. 14, no. 15. P. 11137-11152.

[15] Granberg A.G., Danilov-Daniliyan V.I. et al, 2002. Strategy and sustainable development issues of Russia in the XXI century. Moscow, pp.89-90. 